\title{
Shear behaviour of bond lines in glued laminated timber beams at high temperatures
}

\section{Journal Article}

\section{Author(s):}

Frangi, Andrea; Fontana, Mario; Mischler, Adrian

Publication date:

2004-05

Permanent link:

https://doi.org/10.3929/ethz-b-000050210

Rights / license:

In Copyright - Non-Commercial Use Permitted

Originally published in:

Wood Science and Technology 38(2), https://doi.org/10.1007/s00226-004-0223-y 


\title{
Andrea Frangi - Mario Fontana $\cdot$ Adrian Mischler \\ Shear behaviour of bond lines in glued laminated timber beams at high temperatures
}

Received: 5 November 2001/Published online: 25 March 2004

(C) Springer-Verlag 2004

\begin{abstract}
A comprehensive research project has been carried out at the Swiss Federal Institute of Technology (ETH) on the fire behaviour of timber-concrete composite slabs (Frangi and Fontana 2000). The glued laminated timber beams used for the fire tests were bonded with a one-component polyurethane (1-KPUR) adhesive. As one fire test on a slab showed an unexpected shear failure of a glued laminated timber beam, a series of tests was carried out to study the shear behaviour of different types of adhesives at high temperatures. The first part of the paper describes the results of the shear tests at elevated temperatures, in the second part the shear test results are compared to the fire test on a slab.
\end{abstract}

\section{Introduction}

In recent years one-component polyurethane (1-K-PUR) adhesives have become popular on the European market for the bonding of load-bearing timber components such as glued laminated timber products, finger-joints and Ibeams. Their main advantages are a colourless glueline, easy application of a one-component adhesive and fast hardening within one to three hours without heat application. The 1-K-PUR polyadditive adhesive system hardens with the moisture present in the wood. As there is little knowledge about the behaviour of 1-K-PUR adhesives at high temperatures, five different 1-K-PUR adhesives were tested (Table 1).

Resorcinol-formaldehyde (RF) and phenol-resorcinol-formaldehyde (PRF) adhesives have been used for decades for bonding load-bearing timber components. Fire tests performed in the past with glued laminated timber beams bonded with RF and PRF adhesives never led to concerns about failure of the gluelines (Dorn and Egner 1961, 1967; Dreyer 1969). Therefore a reference series of oven tests was performed with specimens bonded with the resorcinolformaldehyde adhesive Kauresin 460 . On the other hand, there are indications that epoxy based adhesives are sensitive to heat (Barber and Buchanan 1994; Frangi and Fontana 2000), therefore in this study an epoxy adhesive was also 
Table 1 Adhesives tested at high temperatures

\begin{tabular}{lll}
\hline Name of adhesive & Type of adhesive & Company \\
\hline $\begin{array}{l}\text { Kauresin 460, } \\
\text { Hardener 466 }\end{array}$ & resorcinol-formaldehyde & Türmerleim AG, CH-Basel \\
Kauranat 970 & 1-K-polyurethane & Türmerleim AG, CH-Basel \\
Balcotan 107 TR & 1-K-polyurethane & Forbo-CTU AG, CH-Schönenwerd \\
Balcotan 60 190 & 1-K-polyurethane & Forbo-CTU AG, CH-Schönenwerd \\
Purbond HB 110 & 1-K-polyurethane & Collano AG, CH-Sempach-Station \\
Purbond VN 1033 & 1-K-polyurethane & Collano AG, CH-Sempach-Station \\
Araldite AW 136 H, & epoxy & ASTORit AG, CH-Einsiedeln \\
Hardener HY 991 & & \\
\hline
\end{tabular}

tested at high temperatures. However, epoxy based adhesives are not commonly used for bonding glued laminated timber components, but rather an important field of application for these adhesives are timber connections and reinforcements with glued-in rods.

\section{Shear tests at elevated temperatures}

\section{Test specimens and test arrangement}

The experimental tests were carried out within the framework of two diploma theses at the ETH in Zurich (Müller 2000; Schmid 2001). The specimens had dimensions of $112 \times 40 \times 40 \mathrm{~mm}$ (Fig. 1 left). They were produced from glued laminated timber MS 17 according to DIN 4074 with a moisture content of 11$12 \%$. The wood density varied between 456 and $533 \mathrm{~kg} / \mathrm{m}^{3}$.

The shear behaviour of the specimens was experimentally analysed with the test arrangement shown in Fig. 1 left. The loading arrangement was insulated with mineral wool as shown in Fig. 1 right. An industrial air heater allowed the required temperature to be kept constant during the loading of the specimen.

The specimens were heated in an oven to the required constant temperature, transferred as quickly as possible to the heated loading arrangement and finally loaded, reaching failure after approximately 30-60 s. The temperature was continuously measured during the heating and loading of the specimen.
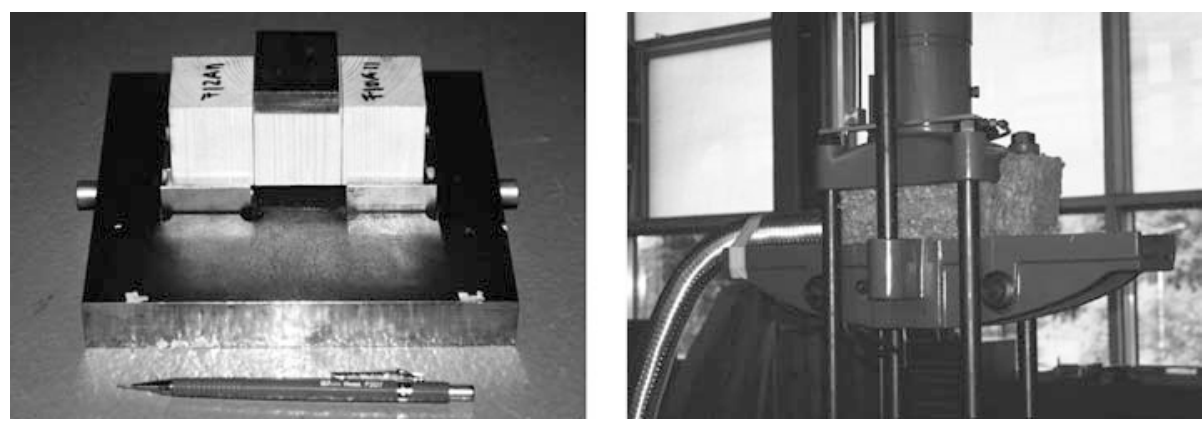

Fig. 1 Test arrangement for shear tests at high temperatures 

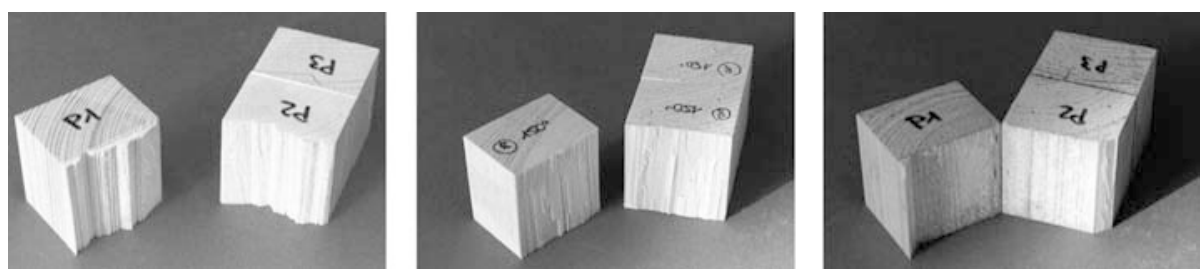

Fig. 2 Typical failure modes: failure of timber outside the glueline at left, failure of the adhesion between adhesive and timber centre and failure of the cohesion of the adhesive right

\section{Tests results}

For each adhesive 74 tests were performed. The temperature ranged between $20^{\circ}$ and $170^{\circ} \mathrm{C}$. The following different failure modes were observed (Fig. 2):

i. Failure in the glueline by loss of cohesion of the adhesive

ii. Failure of the adhesion between adhesive and timber

iii. Failure of timber outside the glueline

Figure 3 shows the mean values of the shear strength and the percentage of the failure mode "cohesion" observed for the adhesive Balcotan 107 TR as a function of temperature. Further, the best linear approximation of the reduction of the shear strength as a function of the temperature was calculated with the least squares method.

From Fig. 3 the following remarks can be drawn:

i. A bi-linear curve with break point at about $70^{\circ} \mathrm{C}$ gives a good approximation of the reduction of the shear resistance as a function of temperature.

ii. A big loss in shear resistance is observed as a function of temperature up to about $70^{\circ} \mathrm{C}$. The mean residual shear resistance at $70^{\circ} \mathrm{C}$ is $40 \%$ of the shear resistance at room temperature. A smaller loss in shear resistance was observed as the temperature increased from $70^{\circ} \mathrm{C}$.

iii. The failure mode "cohesion" was never observed at room temperature. On the other hand, this failure mode was observed with increasing temperature,

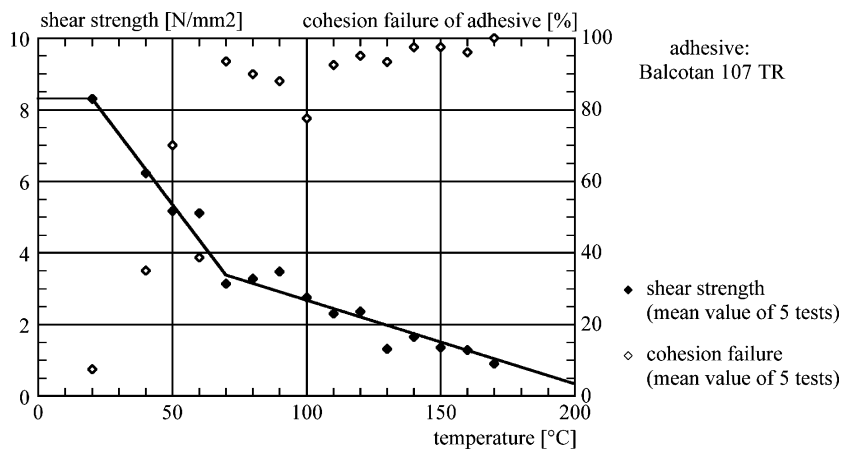

Fig. 3 Mean shear strength and percentage of cohesion failure observed for the adhesive Balcotan 107 TR as a function of temperature 
Table 2 Temperature range at which a change from failure of the adhesion between adhesive and timber to failure of cohesion of the adhesive was observed

\begin{tabular}{lllllll}
\hline $\begin{array}{l}\text { Kauresin } \\
460\end{array}$ & $\begin{array}{l}\text { Kauranat } \\
970\end{array}$ & $\begin{array}{l}\text { Balcotan } \\
107 \mathrm{TR}\end{array}$ & $\begin{array}{l}\text { Balcotan } \\
60190\end{array}$ & $\begin{array}{l}\text { Purbond } \\
\text { HB 110 }\end{array}$ & $\begin{array}{l}\text { Purbond } \\
\text { VN 1033 }\end{array}$ & $\begin{array}{c}\text { Araldite } \\
\text { AW 136 H }\end{array}$ \\
\hline$>170^{\circ} \mathrm{C}$ & $180-190^{\circ} \mathrm{C}$ & $50-60^{\circ} \mathrm{C}$ & $190-200^{\circ} \mathrm{C}$ & $60-70^{\circ} \mathrm{C}$ & $150-160^{\circ} \mathrm{C}$ & $50-60^{\circ} \mathrm{C}$ \\
\hline
\end{tabular}

and for temperatures higher than about $70^{\circ} \mathrm{C}$, only "cohesion" failure occurred.

For calculation of fire resistance it is important to know which temperatures lead to a change from failure of the adhesion between adhesive and timber to failure of the cohesion of the adhesive. Table 2 gives the observed temperature range for the different adhesives tested at high temperatures.

It can be seen that the adhesives Kauresin 460, Kauranat 970, Balcotan 60 190 and Purbond VN 1033 showed cohesion failure of the adhesive at temperatures above $150^{\circ} \mathrm{C}$. On the other hand, for the adhesives Balcotan $107 \mathrm{TR}$, Purbond HB 110 and Araldite AW 136 the cohesion failure of the adhesive was observed at temperatures of about $50-70^{\circ} \mathrm{C}$.

Figure 4 shows the best approximation for the reduction of the shear strength as a function of temperature for the different adhesives tested at high temperatures. Further, Fig. 4 gives the temperature-dependent reduction of the shear strength of timber calculated from all tests with timber failure alone.

From Fig. 4 the following remarks can be drawn:

i. The shear behaviour of the different one-component polyurethane adhesives tested at high temperature strongly depends on the composition of the adhesive. Test results based on one 1-K-PUR adhesive are therefore not valid for other 1-K-PUR adhesives.

ii. The 1-K-PUR adhesives Kauranat 970 and Balcotan 60190 showed more or less the same reduction of shear strength as the reference resorcinol-formaldehyde (RF) adhesive Kauresin 460.

iii. The 1-K-PUR adhesives Purbond VN 1033 and HB 110 showed a greater shear strength reduction compared to the reference resorcinol-formaldehyde (RF) adhesive Kauresin 460, however the differences were quite small.

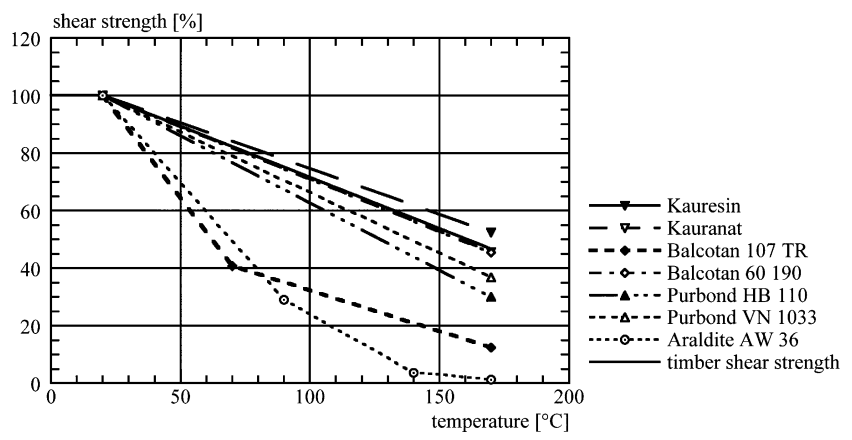

Fig. 4 Reduction of shear strength as a function of temperature for the different adhesives tested at high temperatures 
iv. The 1-K-PUR adhesive Balcotan $107 \mathrm{TR}$, as well as the epoxy adhesive Araldite AW 136, showed shear strength reduction clearly greater than the other adhesives.

Comparison with fire test on a timber-concrete composite slab

A comprehensive research project was carried out at the ETH on the fire behaviour of timber-concrete composite slabs (Frangi 2001). The two types of slabs shown in Fig. 5, along with the two types of connections shown in Fig. 6 were tested during the research project.

In a series of small-scale tests, fire behaviour of the connectors subjected to tension or shear was experimentally analysed. A series of fire tests on slabs looked at the global behaviour of timber-concrete composite slabs. All fire tests were based on ISO-fire exposure and performed at the Swiss Federal Laboratories for Materials Testing and Research in Dübendorf. Detailed experimental results of all tests are described in (Frangi and Fontana 2000). From the slab tests, two tests were performed with beam-type slabs: one with grooves and glued dowels and one with screws (Fig. 7).

The beam-type slab with grooves and Hilti dowels showed an unexpected shear failure of a glued laminated timber beam after 63 min ISO-fire exposure. The shear failure was located in the glueline. After the fire test it was observed that due to air turbulence between the beams the timber beams exhibited an irregular charring (Fig. 8 left). The measured charring rate near the failed glueline was $1.07 \mathrm{~mm} / \mathrm{min}$. Therefore a finite element based calculation model

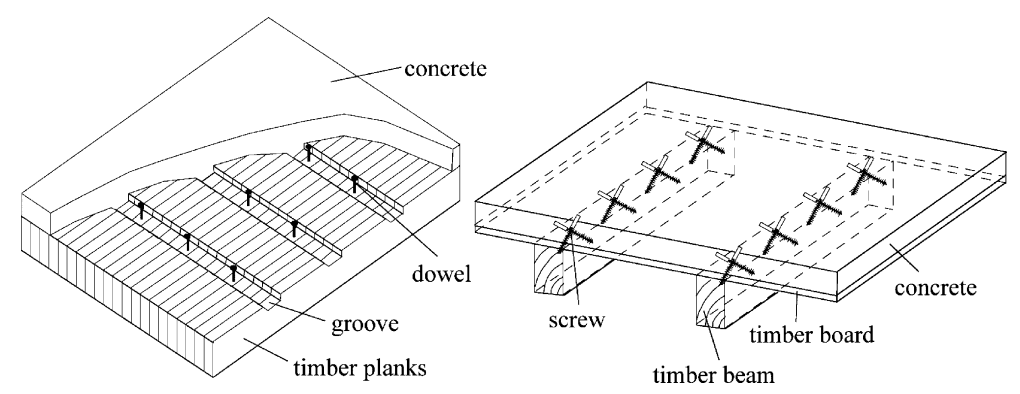

Fig. 5 Design of timber-concrete composite floors
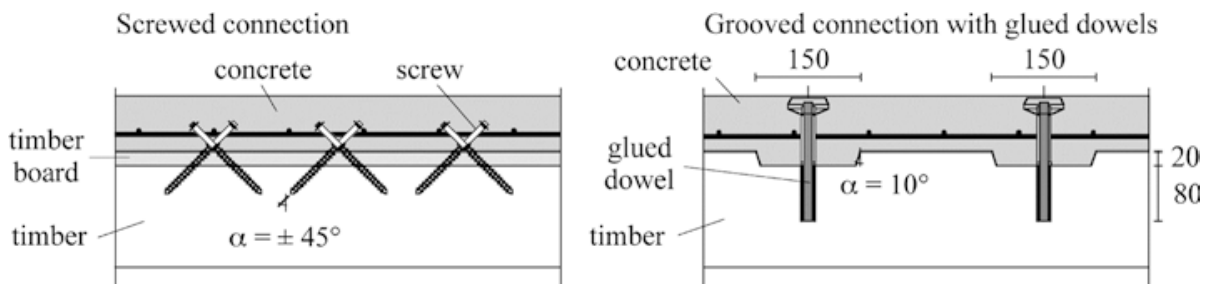

Fig. 6 Screwed connection at left and grooved connection with glued steel dowels right for timber-concrete composite floors 
Hilti timber-concrete composite slab

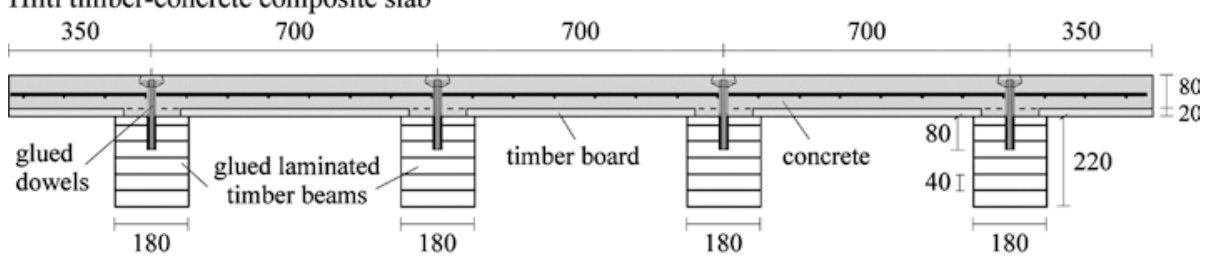

SFS timber-concrete composite slab

(imber board

Fig. 7 Cross-sections of the beam-type slabs: one with grooves and Hilti glued dowels and one with SFS screws exposed to ISO-fire
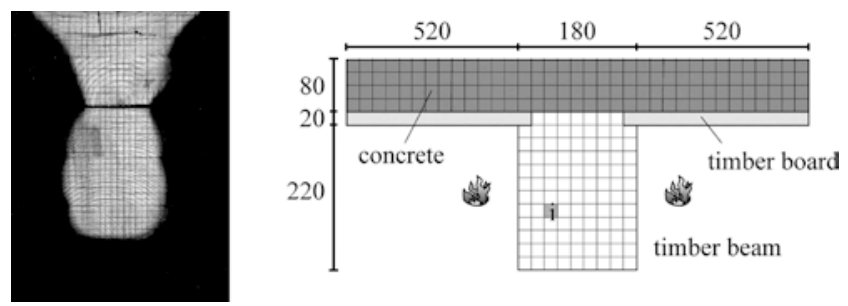

Fig. 8 Cross-section of the timber beam failed after 63 minutes of ISO-fire exposure at left and modelling of cross-section right

was developed to consider the influence of the different measured charring depths. For the model, the cross-section was divided into finite elements (Fig. 8 $r i g h t)$ with different stiffness and strength properties depending on the measured temperature $\Theta_{i}(t)$.

For calculation of the fire resistance of a timber-concrete composite slab exposed to ISO-fire, it is necessary to know the shear strength of timber and bond as a function of temperature. The shear strength of timber at room temperature was assumed according to full-scale tests by Schickhofer and Pischl (1999) which were performed with structural glued-laminated timber beams with sizes used in practice. For reduction of the shear strength of timber as a function of temperature, two different cases were considered:

i. Linear reduction of the shear strength of timber according to the oven test results.

ii. Two-linear reduction of the shear strength of timber according to prEN 1995-1-2 (2000).

A shear strength of the bond as a function of temperature was assumed according to the oven tests. Figure 9 shows the mechanical properties of timber and bond assumed in the calculation model. The calculation model predicted 
Table 3 Comparison of the measured fire resistance $t_{\mathrm{R}, \text { test }}$ with the fire resistance $t_{\mathrm{R}, \text { model }}$ calculated with the mechanical properties shown in Fig. 9

\begin{tabular}{|c|c|c|c|c|c|}
\hline \multirow[t]{2}{*}{ Test } & \multirow[t]{2}{*}{$t_{\mathrm{R}, \text { test }}[\mathrm{min}]$} & \multicolumn{2}{|c|}{ adhesive + timber linear } & \multicolumn{2}{|c|}{ adhesive + timber two-linear } \\
\hline & & $t_{\mathrm{R}, \text { model }}[\mathrm{min}]$ & $t_{\mathrm{R}, \text { test }} / t_{\mathrm{R}, \text { model }}[-]$ & $t_{\mathrm{R}, \text { model }}[\mathrm{min}]$ & $t_{\mathrm{R}, \text { test }} / t_{\mathrm{R}, \text { model }}[-]$ \\
\hline Hilti & 63 & 68 & 0.93 & 66 & 0.95 \\
\hline
\end{tabular}

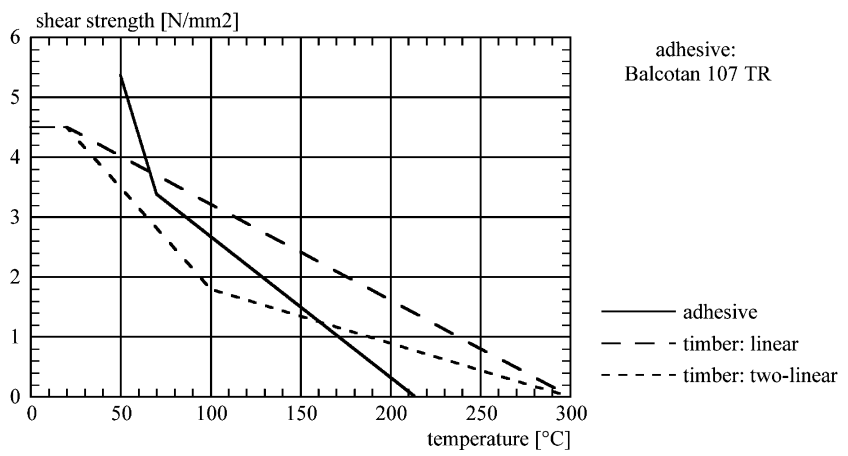

Fig. 9 Shear strength of timber and bond assumed in the calculation model

shear failure of the glueline correctly. Table 3 compares the measured fire resistance $t_{\mathrm{R} \text {,test }}$ with the fire resistance $t_{\mathrm{R} \text {,model }}$ calculated with the mechanical properties shown in Fig. 9. It can be seen that the calculated fire resistance is in good agreement with the fire test result.

\section{Conclusions}

A comprehensive research project was carried out at the ETH on the fire behaviour of timber-concrete composite slabs. The glued laminated timber beams used for the fire tests were bonded with a one-component polyurethane (1-K-PUR) adhesive. After a fire test on a slab showed an unexpected shear failure of a glued laminated timber beam, a series of oven tests was carried out to study the shear behaviour of the 1-K-PUR adhesives at high temperatures.

The oven tests were performed with small shear specimens bonded with seven different adhesives: five types of one-component polyurethane (1-K-PUR) adhesives, one resorcinol-formaldehyde (RF) adhesive and one epoxy adhesive. The oven tests clearly showed that the shear behaviour of the different onecomponent polyurethane adhesives tested at high temperature strongly depends on the type of adhesive. Test results based on one particular 1-K-PUR adhesive are therefore not valid for other 1-K-PUR adhesives. Further, the oven tests demonstrated that the adhesive used for the slab test is sensitive to heat. A big loss in shear resistance was observed as a function of temperature up to about $70^{\circ} \mathrm{C}$. The mean residual shear resistance at $70^{\circ} \mathrm{C}$ was only $40 \%$ of the shear resistance at room temperature. 
For fire design of glued laminated elements, it is important to know the loss of bond strength with increasing temperature and the temperature leading to a change from failure of the adhesion between adhesive and timber to failure of the cohesion of the adhesive. RF and PRF as well as most 1-K-PUR adhesives showed a strength reduction in the range similar to that of spruce and a failure of the cohesion of the adhesive at temperatures higher than $150^{\circ} \mathrm{C}$. On the other hand, for some 1-K-PUR and epoxy adhesives a failure of the cohesion of adhesive was observed at temperatures of about $50-60^{\circ} \mathrm{C}$.

A structural model was developed for the calculation of the fire resistance of the timber-concrete composite slabs using 1-K-PUR adhesives. The fire resistance was calculated taking into account the reduced shear strength of timber and bond at the guidelines from the oven test results. Further, the calculation model based on finite elements permitted consideration of the influence of different charring depths measured during the fire test. The calculated fire resistance was in good agreement with the fire test result.

\section{References}

Barber DJ, Buchanan AH (1994) Fire resistance of epoxied steel rods in Glulam timber. Research report 94/1. Department of Civil Engineering, University of Canterbury, Christchurch, New Zealand

Dorn H, Egner K (1961) Brandversuche mit geleimten Holzbauteilen. Holz Zentralbl 87

Dorn H, Egner K (1967) Brandversuche an Brettschichtverleimten Holzträger unter Biegebeanspruchung. Holz Roh Werkst 25

Dreyer R (1969) Brandverhalten von Holzträgern unter Biege- und Feuerbeanspruchung. Bauen Holz 5

prEN 1995-1-2 (2000) Design of timber structures. General rules-structural fire design. CEN-European Committee for Standardization, Brussels

Frangi A, Fontana M (2000) Versuche zum Tragverhalten von Holz-Beton-Verbunddecken bei Raumtemperatur und Normbrandbedingungen. Institute of Structural Engineering (IBK), ETH Zurich, IBK report 249. Birkhäuser, Basel. http://e-collection.ethbib.ethz.ch/cgi-bin/ show.pl?type $=$ incoll $\& n r=791$. Cited 16 February 2004

Frangi A (2001) Brandverhalten von Holz-Beton-Verbunddecken. Institute of Structural Engineering (IBK), ETH Zurich, IBK report 269. Birkhäuser, Basel. http://e-collection.ethbib.ethz.ch/cgi-bin/show.pl?type $=$ incoll\&nr $=771$. Cited 16 February 2004

Müller R (2000) Verhalten von auf Schub beanspruchten BSHfugen bei hohen Temperaturen. Diplomarbeit in Konstruktion, Institute of Structural Engineering (IBK), ETH Zurich

Schickhofer G, Pischl R (1999) Ermittlung beanspruchungsgerechter Schubfestigkeiten für eine wirtschaftliche Bauteilbemessung und Implementierung in nationalen und internationalen Normern. Report LR9901, Technical University Graz

Schmid M (2001) Verhalten von auf Schub beanspruchten BSH-Klebstofffugen bei hohen Temperaturen. Diplomarbeit in Konstruktion. Institute of Structural Engineering (IBK), ETH Zurich 